\title{
INTERFERENSI FONOLOGI DIALEK MELAYU NATUNA DALAM PENGGUNAAN BAHASA INDONESIA DI RUANG PUBLIK KECAMATAN BUNGURAN TIMUR LAUT KABUPATEN NATUNA
}

\author{
Sopatri Dewi, Wahyu Indrayati, Riau Wati \\ Pendidikan Bahasa dan Sastra Indonesia, Universitas Maritim Raja Ali Haji \\ Pos-el: sopatridewi@gmail.com
}

\begin{abstract}
Abstrak
Penelitian ini membahas tentang interferensi yang difokuskan pada bentuk fonologi, hal ini dilatarbelakangi oleh adanya perubahan bunyi fonem vokal, fonem konsonan, fonem vokal menjadi fonem diftong. Tujuan penelitian ini adalah untuk menemukan dan mendeskripsikan interferensi fonologi jenis perubahan bunyi fonem dialek Melayu Natuna dalam penggunaan bahasa Indonesia di ruang publik Kecamatan Bunguran Timur Laut, Kabupaten Natuna. Teknik pengumpulan data menggunakan teknik sadap yang dilakukan pada acara resmi diselenggarakan oleh pihak Desa. Untuk analisis data langkah yang dilakukan peneliti yaitu mentranskip data, mengidentifikasi data berdasarkan jenis interferensi fonologi yang terjadi, mengklasifikasi data berdasarkan interferensi fonologi jenis perubahan bunyi fonem, menginterpretasi data, dan mendeskripsikan hasil yang berupa kalimat yang mengandung interferensi fonologi. Dalam penelitian ini telah ditemukan beberapa perubahan bunyi fonem antaranya fonem vokal /a/, /i/, /u/, /e/, /ə/, dan /o/. Perubahan bunyi fonem konsonan $/ \mathrm{r} /, / \mathrm{p} /$, /l/, /t/, / / /, /f/, /v/ dan /c/. Perubahan bunyi fonem vokal /a/ dengan fonem diftong /Jw/. Interferensi yang terjadi dalam penggunaan bahasa Indonesia di ruang publik Kecamatan Bunguran Timur Laut, Kabupaten Natuna lebih banyak melakukan perubahan bunyi fonem vokal /a/ baik pada suku kata pertama, kedua, dan bahkan pada suku kata ketiga.
\end{abstract}

Kata Kunci : Interferensi, fonologi, dialek Melayu Natuna

\begin{abstract}
This study discusses interference focused on phonological forms, this is motivated by changes in the sound of vocal phonemes, consonant phonemes, vocal phonemes into diphthongs phonemes. The purpose of this study was to find and describe phonological interference in the type of phoneme sound changes in the Malay Natuna dialect in the use of Indonesian in public spaces in the Bunguran Timur Laut District, Natuna Regency. Data collection techniques using tapping techniques carried out at official events organized by the Village. For data analysis, the steps taken by researchers are transcribing data, identifying data based on the type of phonological interference that occurs, classifying data based on phonological interference, type of phoneme sound change, interpreting data, and describing results in the form of sentences containing phonological interference. In this study several phonemic sound changes have been found including the vocal phonemes $/ a /, / \mathrm{l} /, \mid \mathrm{l} /, / \mathrm{l} /$, $/ \partial /$, and $/ \mathrm{o} /$. Changes in consonant phonemes $/ \mathrm{r} /, / \mathrm{p} /, \mathrm{ll} /, \mathrm{lt} /, \mathrm{k} /, \mid \mathrm{f} /, \mathrm{/v} /$ and $/ \mathrm{c} /$. Change the sound of the vocal phonemes /a/ with the diphthong phoneme /Jw/. Interference that occurs in the use of Indonesian in public spaces Bunguran Timur Laut District, Natuna Regency, changes the sound of vowel phonemes /a/ both in the first, second, and even third syllables.
\end{abstract}

Key Words: Interference, phonology, Natuna Malay dialect 


\section{PENDAHULUAN}

Bangsa Indonesia terdiri dari berbagai jenis suku bangsa yang tidak dapat lepas dari bahasa. Bahasa yang digunakan dapat berupa bahasa daerah (bahasa pertama) dan bahasa nasional (bahasa kedua). Bahasa daerah digunakan sebagai alat komunikasi untuk warga sesuku. Bahasa daerah yang ada di Indonesia sangat beragam. Salahsatu diantaranya adalah bahasa Melayu. Menurut Wati (2014:38) bahasa Melayu termasuk rumpun bahasa Austronesia (AN). Rumpun bahasa ini meliputi beratus-ratus bahasa yang tersebar di Asia Tenggara (Indonesia, Filifina, Semenanjung Malaysia dan beberapa daerah pedalaman Indo-Cina) di Oceania.

Pada umumnya masyarakat Melayu Kepulauan Riau berkomunikasi menggunakan bahasa Melayu, termasuk masyarakat Melayu Kecamatan Bunguran Timur Laut, Kabupaten Natuna. Kabupaten Natuna memiliki dialek Melayu yang berbeda dengan dialek-dialek Melayu di Kabupaten lain. Dialek Melayu Natuna mempunyai ciri khas yaitu lebih banyak menggunakan fonem /ə/, dan /e/. Misalnya, [manə], [buət], [tambeh], dan [beRu].

Dengan adanya bahasa daerah di Kecamatan Bunguran Timur Laut. Saat ini, kesadaran masyarakat menggunakan bahasa Indonesia dengan baik dan benar di ruang publik dinilai sangat rendah. Hal ini mengakibatkan terjadinya fenomena interferensi di ruang publik. Fenomena interferensi yaitu masuknya bahasa daerah ke dalam penggunaan bahasa Indonesia. Hal ini dapat dilihat pada acara resmi yang dilaksanakan oleh pemerintah Desa.

Fenomena interferensi secara langsung mempengaruhi penggunaan bahasa Indonesia tergerus terutama dikalangan masyarakat yang menghadiri kegiatan di ruang publik serta generasi muda yang banyak berkomunikasi ragam lisan dan ragam tulisan di jejaringan sosial. Mereka merasa nyaman menggunakan bahasa daerah dalam bahasa Indonesia, padahal struktur dan kata-katanya tidak sesuai kaidah tata bahasa yang ada di EBI.

Berdasarkan uraian di atas, maka penelitian ini difokuskan pada interferensi fonologi jenis perubahan bunyi fonem dialek Melayu Natuna dalam penggunaan bahasa Indonesia di ruang publik Kecamatan Bunguran Timur Laut, Kabupaten Natuna.

\section{METODE PENELITIAN}

Penelitian tentang interferensi bahasa ini berkaitan dengan fenomena kebahasaan yang bersifat natural. Artinya, data yang dikumpulkan berasal dari lingkungan yang nyata dan apa adanya. Jenis penelitian ini adalah penelitian deskriptif. Hal ini disebabkan oleh data yang terkumpul, dianalisis, serta dipaparkan secara deskriptif. Penelitian deskriptif adalah pengkajian ilmiah yang dilakukan untuk memperoleh informasi tentang suatu gejala pada saat penelitian itu dilakukan sehingga dapat diberikan secara sistematis, baik dengan maupun tanpa menguji hipotesis, dan tanpa mengadakan perlakuan terhadap variabel-variabel yang diamati (Malik, 2016:3).

\section{Teknik Pengumpulan Data}

Teknik yang digunakan untuk mengumpulkan data dalam penelitian ini yaitu teknik sadap.

\section{Teknik Analisis Data}

Analisis data merupakan suatu upaya pengolahan data dengan cara mentranskrip data (data yang sudah didapat dalam bentuk rekaman pada acara formal yang diselenggarakan oleh pihak Desa, Kecamatan Bunguran Timur Laut, Kabupaten Natuna diubah dalam bentuk tulisan). Mengidentifikasi data (data dibagi berdasarkan jenis interferensi fonologi yang terjadi dalam penggunaan bahasa Indonesia di ruang publik Kecamatan Bunguran Timur Laut, Kabupaten Natuna. Mengklasifikasi data (setelah itu data dibagi berdasarkan jenis interferensi fonologi yang terjadi. Data yang 
dilanjutkan dengan mengklasifikasikan berdasarkan interferensi fonologi jenis perubahan bunyi fonem). Menginterpretasi data (interpretasi data merupakan upaya untuk memperoleh arti makna yang lebih mendalam dan luas terhadap hasil penelitian yang dilakukan.

\section{HASIL PENELITIAN DAN PEMBAHASAN}

Berdasarkan proses pengumpulan data yang telah peneliti lakukan di lapangan, peneliti menemukan beberapa kosakata yang mengandung interferensi fonologi jenis perubahan bunyi. Menurut Weinreich (dalam Aslinda dan Leni Syafyahya, 2010:67) interferensi fonologi terjadi karena adanya interferensi dalam bidang bunyi. Interferensi fonologi dalam bidang bunyi tersebut yaitu perubahan bunyi fonem pada bahasa kedua yang dipengaruhi oleh bahasa pertama.

Penelitian ini mengacu pada interferensi fonologi jenis perubahan bunyi dalam penggunaan bahasa Indonesia akibat terjadinya interferensi dialek Melayu Natuna di kantor Desa Kecamatan Bunguran Timur Laut, Kabupaten Natuna pada saat pelaksanaan musyawarah di Desa Pengadah, Desa Tanjung, Desa Limau Manis, Desa Selemam, dan Desa Kelanga. Pelatihan di Desa Ceruk. Pelantikan Desa Sebadai Hulu. Berikut ini adalah data peneliti yang mengalami perubahan bunyi fonem.

\section{Perubahan Bunyi Fonem Vokal 1.1 Perubahan Bunyi Fonem Vokal /a/ Dengan Fonem Vokal /a/}

Berikut ini adalah data yang termasuk ke dalam perubahan bunyi fonem vokal /a/ dengan fonem vokal /ə/ pada suku kata pertama, kedua, dan ketiga tanpa mengubah arti yang terjadi akibat interferensi dialek Melayu Natuna pada acara musyawarah di Desa Pengadah, Desa Selemam, Desa Limau Manis, Desa Kelanga, dan Desa Tanjung. Pelantikan di Desa Ceruk. Pelatihan di Desa Sebadai
Hulu, Kecamatan Bunguran Timur Laut sebagai berikut:

a. Perubahan Bunyi Fonem Vokal /a/ Dengan Fonem Vokal /a/ Pada Suku Kata Pertama

\begin{tabular}{|c|c|c|c|}
\hline $\begin{array}{l}\text { Fonem } \\
\text { vokal }\end{array}$ & $\begin{array}{l}\text { Baha } \\
\text { sa } \\
\text { Indo } \\
\text { nesia }\end{array}$ & $\begin{array}{l}\text { Bahasa } \\
\text { Melayu } \\
\text { dialek } \\
\text { Melayu } \\
\text { Natuna }\end{array}$ & Pembahasan \\
\hline$/ \mathrm{a} />/ \partial /$ & ya & [y므] & $\begin{array}{l}\text { Pada kata ya } \\
\text { mengalami } \\
\text { perubahan bunyi } \\
\text { fonem vokal /a/ } \\
\text { dengan fonem } \\
\text { vokal /a/ pada } \\
\text { suku kata } \\
\text { pertama, } \\
\text { sehingga kata } \\
\text { [ya] berubah } \\
\text { menjadi [yə]. }\end{array}$ \\
\hline
\end{tabular}

b. Perubahan Bunyi Fonem Vokal /a/ Dengan Fonem Vokal /a/ Pada Suku Kata Kedua

\begin{tabular}{|c|c|c|c|}
\hline $\begin{array}{l}\text { Fonem } \\
\text { vokal }\end{array}$ & $\begin{array}{l}\text { Baha } \\
\text { sa } \\
\text { Indo } \\
\text { nesia }\end{array}$ & $\begin{array}{l}\text { Bahasa } \\
\text { Melayu } \\
\text { dialek } \\
\text { Melayu } \\
\text { Natuna }\end{array}$ & Pembahasan \\
\hline $\mid a />/ \partial /$ & saya & [sayㅁ] & $\begin{array}{l}\text { Pada kata saya } \\
\text { mengalami } \\
\text { perubahan bunyi } \\
\text { fonem vokal /a/ } \\
\text { dengan fonem } \\
\text { vokal /ə/ pada } \\
\text { suku kata kedua, } \\
\text { sehingga kata } \\
\text { [saya] berubah } \\
\text { menjadi [sayə]. }\end{array}$ \\
\hline
\end{tabular}

c. Perubahan Bunyi Fonem Vokal /a/ Dengan Fonem Vokal /a/ Pada Suku Kata Ketiga

\begin{tabular}{|c|c|c|c|}
\hline $\begin{array}{l}\text { Fonem } \\
\text { vokal }\end{array}$ & $\begin{array}{l}\text { Baha } \\
\text { sa } \\
\text { Indo } \\
\text { nesia }\end{array}$ & $\begin{array}{l}\text { Bahasa } \\
\text { Melayu } \\
\text { dialek } \\
\text { Melayu } \\
\text { Natuna }\end{array}$ & Pembahasan \\
\hline $\mid \mathrm{a} />/ \partial /$ & $\begin{array}{l}\text { kepa } \\
\text { da }\end{array}$ & [kəpadə] & $\begin{array}{l}\text { Pada kata kepada } \\
\text { mengalami } \\
\text { perubahan bunyi } \\
\text { fonem vokal /a/ } \\
\text { dengan fonem } \\
\text { vokal /ə/ pada } \\
\text { suku kata ketiga, } \\
\text { sehingga kata } \\
\text { [kepada] berubah } \\
\text { menjadi } \\
\text { [kəpadə]. }\end{array}$ \\
\hline
\end{tabular}




\subsection{Perubahan Bunyi Fonem Vokal /a/ Dengan Fonem Vokal /e/}

Berikut ini adalah data yang termasuk ke dalam perubahan bunyi fonem /a/ dengan fonem vokal /e/ pada suku kata pertama dan kedua tanpa mengubah arti yang terjadi akibat interferensi dialek Melayu Natuna pada acara musyawarah di Desa Pengadah, Desa Selemam, Desa Limau Manis, Desa Kelanga, Desa Tanjung. Pelantikan di Desa Ceruk, Kecamatan Bunguran Timur Laut sebagai berikut:

a. Perubahan Bunyi Fonem Vokal /a/ Dengan Fonem Vokal /e/ Pada Suku Kata Pertama

\begin{tabular}{|l|l|l|l|}
\hline $\begin{array}{l}\text { Fonem } \\
\text { vokal }\end{array}$ & $\begin{array}{l}\text { Baha } \\
\text { Sa } \\
\text { Indo } \\
\text { nesia }\end{array}$ & $\begin{array}{l}\text { Bahasa } \\
\text { Melayu } \\
\text { dialek } \\
\text { Melayu } \\
\text { Natuna }\end{array}$ & Pembahasan \\
\hline$/ \mathrm{a} / \mathrm{l} / \mathrm{e} /$ & datan & [detay] & $\begin{array}{l}\text { Pada kata datang } \\
\text { mengalami } \\
\text { perubahan bunyi } \\
\text { fonem vokal /a/ } \\
\text { dengan fonem } \\
\text { vokal /e/ pada } \\
\text { suku kata } \\
\text { pertama, kata } \\
\text { sehingga bah } \\
\text { [datang] berubah } \\
\text { menjadi [detan]. }\end{array}$ \\
\hline
\end{tabular}

b. Perubahan Bunyi Fonem Vokal /a/ Dengan Fonem Vokal /e/ Pada Suku Kata Kedua

\begin{tabular}{|c|c|c|c|}
\hline $\begin{array}{l}\text { Fonem } \\
\text { vokal }\end{array}$ & $\begin{array}{l}\text { Baha } \\
\text { sa } \\
\text { Indo } \\
\text { nesia }\end{array}$ & $\begin{array}{l}\text { Bahasa } \\
\text { Melayu } \\
\text { dialek } \\
\text { Melayu } \\
\text { Natuna }\end{array}$ & Pembahasan \\
\hline$/ \mathrm{a} />/ \mathrm{e} /$ & $\begin{array}{l}\text { namb } \\
\text { eh }\end{array}$ & [nambeh] & $\begin{array}{l}\text { Pada kata } \\
\text { nambah } \\
\text { mengalami } \\
\text { perubahan bunyi } \\
\text { fonem vokal /a/ } \\
\text { dengan fonem } \\
\text { vokal /e/ pada } \\
\text { suku kata kedua, } \\
\text { sehingga kata } \\
\text { [nambah] } \\
\text { berubah menjadi } \\
\text { [nambeh]. }\end{array}$ \\
\hline
\end{tabular}

1.3 Perubahan Bunyi Fonem Vokal /a/ Dengan Fonem Vokal /e/ Dan

\section{Perubahan Bunyi Fonem Vokal /a/} Dengan Fonem Vokal /ə/

Berikut ini adalah data yang termasuk ke dalam perubahan bunyi 2 fonem vokal yaitu fonem vokal /a/ dengan fonem vokal le/ pada suku kata pertama dan kedua. perubahan bunyi fonem vokal /a/ dengan fonem vokal /ə/ pada suku kata kedua dan ketiga tanpa mengubah arti yang terjadi akibat interferensi dialek Melayu Natuna pada acara musyawarah di Desa Pengadah, Desa Selemam, Desa Limau Manis, Desa Kelanga, Desa Tanjung. Pelatihan di Desa Ceruk. Pelantikan di Desa Sebadai Hulu, Kecamatan Bunguran Timur Laut sebagai berikut:

a. Perubahan Bunyi Fonem Vokal /a/ Dengan Fonem Vokal /e/ Suku Kata Pertama Dan Perubahan Bunyi Fonem Vokal /a/ Dengan Fonem Vokal /a/ Pada Suku Kata Kedua

\begin{tabular}{|c|c|c|c|}
\hline $\begin{array}{l}\text { Fonem } \\
\text { vokal }\end{array}$ & $\begin{array}{l}\text { Baha } \\
\text { sa } \\
\text { Indo } \\
\text { nesia }\end{array}$ & $\begin{array}{l}\text { Bahasa } \\
\text { Melayu } \\
\text { dialek } \\
\text { Melayu } \\
\text { Natuna }\end{array}$ & Pembahasan \\
\hline $\begin{array}{l}l \mathrm{a} />/ \mathrm{e} / \\
/ \mathrm{a} />/ \mathrm{a} /\end{array}$ & mana & [meno] & $\begin{array}{l}\text { Pada kata mana } \\
\text { mengalami } \\
\text { perubahan bunyi } \\
\text { fonem vokal /a/ } \\
\text { dengan fonem } \\
\text { vokal /e/ pada } \\
\text { suku } \\
\text { pertama kata } \\
\text { perubahan bunyi } \\
\text { fonem vokal /a/ } \\
\text { dengan fonem } \\
\text { vokal /a/ pada } \\
\text { suku kata kedua, } \\
\text { sehingga kata } \\
\text { [mana] berubah } \\
\text { menjadi [menə]. }\end{array}$ \\
\hline
\end{tabular}

b. Perubahan Bunyi Fonem Vokal /a/ Dengan Fonem Vokal /e/ Pada Suku Kata Kedua Dan Perubahan Bunyi Fonem Vokal /a/ Dengan Fonem Vokal /a/ Pada Suku Kata Ketiga

\begin{tabular}{|c|c|c|c|}
\hline $\begin{array}{l}\text { Fonem } \\
\text { vokal }\end{array}$ & $\begin{array}{l}\text { Baha } \\
\text { sa } \\
\text { Indo } \\
\text { nesia }\end{array}$ & $\begin{array}{l}\text { Bahasa } \\
\text { Melayu } \\
\text { dialek } \\
\text { Melayu } \\
\text { Natuna }\end{array}$ & Pembahasan \\
\hline $\begin{array}{l}/ \mathrm{a} />/ \mathrm{e} / \\
/ \mathrm{a} />/ \mathrm{a} /\end{array}$ & $\begin{array}{l}\text { Segal } \\
\text { a }\end{array}$ & [səgelelə] & $\begin{array}{l}\text { Kata segala } \\
\text { mengalami }\end{array}$ \\
\hline
\end{tabular}




\begin{tabular}{|l|l|l|}
\hline & perubahan bunyi \\
& fonem vokal /a/ \\
dengan fonem \\
vokal /e/ pada \\
suku kata kedua \\
dan perubahan \\
bunyi fonem \\
vokal /a/ dengan \\
fonem vokal /a/ \\
pada suku kata \\
ketiga sehingga \\
kata [segala] \\
berubah menjadi \\
[sogelo].
\end{tabular}

\subsection{Perubahan Bunyi Fonem Vokal /a/ Dengan Fonem Vokal /i/}

Berikut ini adalah data yang termasuk ke dalam perubahan bunyi fonem vokal /a/ dengan fonem vokal /i/ pada suku kata kedua tanpa mengubah arti yang terjadi akibat interferensi dialek Melayu Natuna pada acara musyawarah di Desa Pengadah, Desa Selemam, dan Desa Kelanga. Pelatihan di Desa Ceruk, Kecamatan Bunguran Timur Laut sebagai berikut:

\begin{tabular}{|l|l|l|l|}
\hline $\begin{array}{l}\text { Fonem } \\
\text { vokal }\end{array}$ & $\begin{array}{l}\text { Baha } \\
\text { sa } \\
\text { Indo } \\
\text { nesia }\end{array}$ & $\begin{array}{l}\text { Bahasa } \\
\text { Melayu } \\
\text { dialek } \\
\text { Melayu } \\
\text { Natuna }\end{array}$ & Pembahasan \\
\hline$/ \mathrm{a} / \mathrm{\text {i}} /$ & buat & {$[$ buit] } & $\begin{array}{l}\text { Pada kata buat } \\
\text { mengalami } \\
\text { perubahan bunyi } \\
\text { fonem vokal /a/ } \\
\text { dengan fonem } \\
\text { vokal /i/ pada } \\
\text { suku kata kedua, } \\
\text { sehingga kata } \\
\text { [buat] } \\
\text { berubah menjadi } \\
\text { [buit]. }\end{array}$ \\
\hline
\end{tabular}

\subsection{Perubahan Bunyi Fonem Vokal /i/ Dengan Fonem Vokal /e/}

Berikut ini adalah data yang termasuk ke dalam perubahan bunyi $\mathrm{n}$ fonem vokal /i/ dengan fonem vokal /e/ pada suku kata kedua dan ketiga tanpa mengubah arti yang terjadi akibat interferensi dialek Melayu Natuna pada acara musyawarah di Desa Pengadah, Desa Tanjung, Desa Limau Manis, Desa Selemam, dan Desa
Kelanga. Pelantikan di Desa Sebadai Hulu. Pelatihan di Desa Ceruk, Kecamatan Bunguran Timur Laut sebagai berikut:

a. Perubahan Bunyi Fonem Vokal /i/ Dengan Fonem Vokal /e/ Pada Suku Kata Kedua

\begin{tabular}{|l|l|l|l|}
\hline $\begin{array}{l}\text { Fonem } \\
\text { vokal }\end{array}$ & $\begin{array}{l}\text { Baha } \\
\text { sa } \\
\text { Indo } \\
\text { nesia }\end{array}$ & $\begin{array}{l}\text { Bahasa } \\
\text { Melayu } \\
\text { dialek } \\
\text { Melayu } \\
\text { Natuna }\end{array}$ & Pembahasan \\
\hline$/ \mathrm{i} />/ \mathrm{e} /$ & lebih & {$[$ ləbeh] } & $\begin{array}{l}\text { Pada kata lebih } \\
\text { mengalami } \\
\text { perubahan bunyi } \\
\text { fonem vokal /i/ } \\
\text { dengan fonem } \\
\text { vokal /e/ pada } \\
\text { suku kata kedua, } \\
\text { sehingga kata } \\
\text { [lebih] berubah } \\
\text { menjadi [lebeh] }\end{array}$ \\
\hline
\end{tabular}

b. Perubahan Bunyi Fonem Vokal /i/ Dengan Fonem Vokal /e/ Pada Suku Kata Ketiga

\begin{tabular}{|c|c|c|c|}
\hline $\begin{array}{l}\text { Fonem } \\
\text { vokal }\end{array}$ & $\begin{array}{l}\text { Baha } \\
\text { sa } \\
\text { Indo } \\
\text { nesia }\end{array}$ & $\begin{array}{l}\text { Bahasa } \\
\text { Melayu } \\
\text { dialek } \\
\text { Melayu } \\
\text { Natuna }\end{array}$ & Pembahasan \\
\hline$/ \mathrm{i} />\mathrm{e} /$ & $\begin{array}{l}\text { peny } \\
\text { akit }\end{array}$ & [pəñaket] & $\begin{array}{l}\text { Pada kata } \\
\text { penyakit } \\
\text { mengalami } \\
\text { perubahan bunyi } \\
\text { fonem vokal /i/ } \\
\text { dengan fonem } \\
\text { vokal /e/ pada } \\
\text { suku kata ketiga, } \\
\text { sehingga kata } \\
\text { [penyakit] } \\
\text { berubah menjadi } \\
\text { [pəñaket]. }\end{array}$ \\
\hline
\end{tabular}

\subsection{Perubahan Bunyi Fonem Vokal /ə/ Dengan Fonem Vokal /i/}

Berikut ini adalah data yang termasuk ke dalam perubahan bunyi fonem vokal /ə/ dengan fonem vokal /i/ pada suku kata kedua tanpa mengubah arti yang terjadi akibat interferensi dialek Melayu Natuna pada acara musyawarah di Desa Limau Manis, Desa Tanjung, Desa Selemam, dan Desa Kelanga, Kecamatan Bunguran Timur Laut sebagai berikut: 


\begin{tabular}{|l|l|l|l|}
\hline $\begin{array}{l}\text { Fonem } \\
\text { vokal }\end{array}$ & $\begin{array}{l}\text { Baha } \\
\text { sa } \\
\text { Indo } \\
\text { nesia }\end{array}$ & $\begin{array}{l}\text { Bahasa } \\
\text { Melayu } \\
\text { dialek } \\
\text { Melayu } \\
\text { Natuna }\end{array}$ & Pembahasan \\
\hline$/ \mathrm{\partial}>/ \mathrm{i} / /$ & sistə & {$[$ sistim] } & $\begin{array}{l}\text { Pada kata sistem } \\
\text { mengalami } \\
\text { perubahan bunyi } \\
\text { fonem vokal /a/ } \\
\text { dengan fonem } \\
\text { vokal /i/ pada } \\
\text { suku kata kedua, } \\
\text { sehingga kata } \\
\text { [sistem] berubah } \\
\text { menjadi [sistim]. }\end{array}$ \\
\hline
\end{tabular}

\subsection{Perubahan Bunyi Fonem Vokal /u/ Dengan Fonem Vokal /o/}

Berikut ini adalah data yang termasuk ke dalam perubahan bunyi fonem vokal $/ \mathrm{u} /$ dengan fonem vokal /o/ pada suku kata kedua dan ketiga tanpa mengubah arti yang terjadi akibat interferensi dialek Melayu Natuna pada acara musyawarah di Desa Pengadah, Desa Tanjung, Desa Limau Manis, Desa Selemam, dan Desa Kelanga. Pelantikan di Desa Sebadai Hulu. Pelatihan di Desa Ceruk, Kecamatan Bunguran Timur Laut sebagai berikut:

a. Perubahan Bunyi Fonem Vokal /u/ Dengan Fonem Vokal /o/ Pada Suku Kedua

\begin{tabular}{|l|l|l|l|}
\hline $\begin{array}{l}\text { Fonem } \\
\text { vokal }\end{array}$ & $\begin{array}{l}\text { Baha } \\
\text { Sa } \\
\text { Indo } \\
\text { nesia }\end{array}$ & $\begin{array}{l}\text { Bahasa } \\
\text { Melayu } \\
\text { dialek } \\
\text { Melayu } \\
\text { Natuna }\end{array}$ & Pembahasan \\
\hline$/ \mathrm{u} />/ \mathrm{o} /$ & masu & {$[$ maso?] } & $\begin{array}{l}\text { Pada kata masuk } \\
\text { mengalami } \\
\text { perubahan bunyi } \\
\text { fonem vokal /u/ } \\
\text { dengan fonem } \\
\text { vokal /o/ pada } \\
\text { suku kata kedua, } \\
\text { sehingga kata } \\
\text { [masuk] berubah } \\
\text { menjadi } \\
\text { [masok]. }\end{array}$ \\
\hline
\end{tabular}

b. Perubahan Bunyi Fonem Vokal /u/ Dengan Fonem Vokal /o/ Pada Suku Ketiga

\begin{tabular}{|l|l|l|l|}
\hline $\begin{array}{l}\text { Fonem } \\
\text { vokal }\end{array}$ & $\begin{array}{l}\text { Baha } \\
\text { sa } \\
\text { Indo } \\
\text { nesia }\end{array}$ & $\begin{array}{l}\text { Bahasa } \\
\text { Melayu } \\
\text { dialek } \\
\text { Melayu } \\
\text { Natuna }\end{array}$ & Pembahasan \\
\hline$/ \mathrm{u} />/ \mathrm{o} /$ & sepul & [səpuloh] & $\begin{array}{l}\text { Pada kata } \\
\text { sepuluh } \\
\text { mengalami } \\
\text { uh }\end{array}$ \\
& & $\begin{array}{l}\text { fonem vokahan bunyi } \\
\text { dengan fonem } \\
\text { vokal /o/ pada } \\
\text { suku kata ketiga, } \\
\text { sehingga kata } \\
\text { [sepuluh] } \\
\text { berubah menjadi } \\
\text { [səpuloh] }\end{array}$ \\
\hline
\end{tabular}

\subsection{Perubahan Bunyi Fonem Vokal /o/ Dengan Fonem Vokal /u/}

Berikut ini adalah data yang termasuk ke dalam perubahan bunyi fonem vokal /o/ dengan fonem vokal /u/ pada suku kata pertama tanpa mengubah arti yang terjadi akibat interferensi dialek Melayu Natuna pada acara musyawarah di Desa Pengadah, Desa Tanjung, Desa Limau Manis, Desa Selemam, dan Desa Kelanga. Pelatihan di Desa Ceruk, Kecamatan Bunguran Timur Laut sebagai berikut:

\begin{tabular}{|l|l|l|l|}
\hline $\begin{array}{l}\text { Fonem } \\
\text { vokal }\end{array}$ & $\begin{array}{l}\text { Baha } \\
\text { sa } \\
\text { Indo } \\
\text { nesia }\end{array}$ & $\begin{array}{l}\text { Bahasa } \\
\text { Melayu } \\
\text { dialek } \\
\text { Melayu } \\
\text { Natuna }\end{array}$ & Pembahasan \\
\hline$/ \mathrm{o} / \mathrm{/u} /$ & boleh & [buleh] & $\begin{array}{l}\text { Pada kata boleh } \\
\text { mengalami } \\
\text { perubahan bunyi } \\
\text { fonem vokal /o/ } \\
\text { dengan fonem } \\
\text { vokal /u/ pada } \\
\text { suku kata } \\
\text { pertama, kata } \\
\text { sehingga kat kat } \\
\text { [boleh] berubah } \\
\text { menjadi [buleh]. }\end{array}$ \\
\hline
\end{tabular}

\section{Perubahan Bunyi Fonem Konsonan}




\subsection{Pergantian Fonem Konsonan /k/ Dengan Fonem Konsonan /g/}

Berikut ini adalah data yang termasuk ke dalam perubahan bunyi fonem konsonan /k/ dengan /g/ pada suku kata kedua tanpa mengubah arti yang terjadi akibat interferensi dialek Melayu Natuna pada acara musyawarah di Desa Pengadah, Kecamatan Bunguran Timur Laut sebagai berikut:

\begin{tabular}{|c|c|c|c|}
\hline $\begin{array}{l}\text { Fonem } \\
\text { konson } \\
\text { an }\end{array}$ & $\begin{array}{l}\text { Baha } \\
\text { sa } \\
\text { Indo } \\
\text { nesia }\end{array}$ & $\begin{array}{l}\text { Bahasa } \\
\text { Melayu } \\
\text { dialek } \\
\text { Melayu } \\
\text { Natuna }\end{array}$ & Pembahasan \\
\hline$/ \mathrm{k} />/ \mathrm{g} /$ & $\begin{array}{l}\text { angk } \\
\text { at }\end{array}$ & [aygat] & $\begin{array}{l}\text { Pada kata anggat } \\
\text { mengalami } \\
\text { perubahan bunyi } \\
\text { fonem konsonan } \\
/ \mathrm{k} / \text { dengan fonem } \\
\text { konsonan } / \mathrm{g} / \\
\text { pada suku kata } \\
\text { kedua, sehingga } \\
\text { kata [angkat] } \\
\text { berubah menjadi } \\
\text { [angat]. }\end{array}$ \\
\hline
\end{tabular}

\subsection{Perubahan Bunyi Fonem Konsonan /t/ Dengan Fonem Konsonan /d/}

Berikut ini adalah data yang termasuk ke dalam perubahan bunyi fonem konsonan /t/ dengan fonem konsonan /d/ pada suku kata kedua tanpa mengubah arti yang terjadi akibat interferensi dialek Melayu Natuna pada acara musyawarah di Desa Pengadah, Desa Tanjung, Desa Selemam, dan Desa Kelanga, Kecamatan Bunguran Timur Laut sebagai berikut:

\begin{tabular}{|l|l|l|l|}
\hline $\begin{array}{l}\text { Fonem } \\
\text { konson } \\
\text { an }\end{array}$ & $\begin{array}{l}\text { Baha } \\
\text { sa } \\
\text { Indo } \\
\text { nesia }\end{array}$ & $\begin{array}{l}\text { Bahasa } \\
\text { Melayu } \\
\text { dialek } \\
\text { Melayu } \\
\text { Natuna }\end{array}$ & Pembahasan \\
\hline$/ \mathrm{t} / \rightarrow / \mathrm{d} /$ & tentu & {$[$ təndu] } & $\begin{array}{l}\text { Pada kata tentu } \\
\text { mengalami bunyi } \\
\text { perubahan bunyi } \\
\text { fonem konsonan } \\
\text { /t/ dengan fonem } \\
\text { konsonan /d/ } \\
\text { pada suku kata } \\
\text { kedua, sehingga } \\
\text { kata [tentu] }\end{array}$ \\
\hline
\end{tabular}

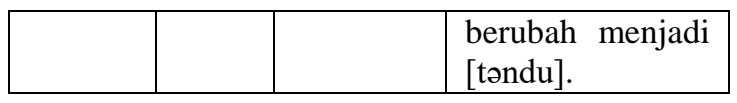

\subsection{Perubahan Bunyi Fonem Konsonan /p/ Dengan Fonem Konsonan /b/}

Berikut ini adalah data yang termasuk ke dalam perubahan bunyi fonem konsonan /p/ dengan /b/ pada suku kata kedua tanpa mengubah arti yang terjadi akibat interferensi dialek Melayu Natuna pada acara musyawarah di Desa Pengadah, Desa Tanjung, Desa Limau Manis, Desa Selemam, dan Desa Kelanga. Pelatihan di Desa Ceruk, Kecamatan Bunguran Timur Laut sebagai berikut:

\begin{tabular}{|l|l|l|l|}
\hline $\begin{array}{l}\text { Fonem } \\
\text { konson } \\
\text { an }\end{array}$ & $\begin{array}{l}\text { Baha } \\
\text { sa } \\
\text { Indo } \\
\text { nesia }\end{array}$ & $\begin{array}{l}\text { Bahasa } \\
\text { Melayu } \\
\text { dialek } \\
\text { Melayu } \\
\text { Natuna }\end{array}$ & Pembahasan \\
\hline$/ \mathrm{p} />/ \mathrm{b} /$ & samp & [sambai] & $\begin{array}{l}\text { Pada kata sampai } \\
\text { mengalami } \\
\text { perubahan bunyi } \\
\text { ai }\end{array}$ \\
& & $\begin{array}{l}\text { /p/dengan fonem } \\
\text { konsonan /b/ } \\
\text { pada suku kata } \\
\text { kedua, sehingga } \\
\text { kata [sampai] } \\
\text { berubah menjadi } \\
\text { [sambai]. }\end{array}$ \\
\hline
\end{tabular}

\subsection{Perubahan Bunyi Fonem Konsonan /// Dengan Fonem Konsonan /?/}

Berikut ini adalah data yang termasuk ke dalam perubahan bunyi fonem konsonan /l/ dengan fonem konsonan / $/ \mathrm{k}$ pada suku kata kedua tanpa mengubah arti yang terjadi akibat interferensi dialek Melayu Natuna pada acara musyawarah di Desa Pengadah, Desa Tanjung, Desa Limau Manis, Desa Selemam, dan Desa Kelanga. Pelatihan di Desa Ceruk, Kecamatan Bunguran Timur Laut sebagai berikut:

\begin{tabular}{|l|l|l|ll|}
\hline $\begin{array}{l}\text { Fonem } \\
\text { konson } \\
\text { an }\end{array}$ & $\begin{array}{l}\text { Baha } \\
\text { sa } \\
\text { Indo } \\
\text { nesia }\end{array}$ & $\begin{array}{l}\text { Bahasa } \\
\text { Melayu } \\
\text { dialek } \\
\text { Melayu } \\
\text { Natuna }\end{array}$ & Pembahasan \\
\\
\hline$/ 1 />l / /$ & kecil & {$[$ kecik] } & Pada kata kecil \\
\hline
\end{tabular}




\begin{tabular}{|l|l|l|}
\hline & mengalami \\
& perubahan bunyi \\
& fonem konsonan \\
& /l/ dengan fonem \\
konsonan $/ ? /$ \\
pada suku kata \\
kedua sehingga \\
kata [kecil] \\
berubah menjadi \\
[kəci?].].
\end{tabular}

\subsection{Perubahan Bunyi Fonem Konsonan} /c/ Dengan Fonem Konsonan /j/

Berikut ini adalah data yang termasuk ke dalam perubahan bunyi fonem konsonan /c/ dengan fonem konsonan /j/ pada suku kata kedua tanpa mengubah arti yang terjadi akibat interferensi dialek Melayu Natuna pada acara musyawarah di Desa Limau Manis, Kecamatan Bunguran Timur Laut sebagai berikut:

\begin{tabular}{|l|l|l|l|}
\hline $\begin{array}{l}\text { Fonem } \\
\text { konson } \\
\text { an }\end{array}$ & $\begin{array}{l}\text { Baha } \\
\text { sa } \\
\text { Indo } \\
\text { nesia }\end{array}$ & $\begin{array}{l}\text { Bahasa } \\
\text { Melayu } \\
\text { dialek } \\
\text { Melayu } \\
\text { Natuna }\end{array}$ & Pembahasan \\
\hline$/ \mathrm{c} />/ \mathrm{j} /$ & kunci & {$[$ kunji] } & $\begin{array}{l}\text { Pada kata kunci } \\
\text { mengalami } \\
\text { perubahan bunyi } \\
\text { fonem konsonan } \\
\text { /c/ dengan fonem } \\
\text { konsonan /j/ } \\
\text { pada suku kata } \\
\text { kedua, sehingga } \\
\text { kata [kunci] } \\
\text { berubah menjadi } \\
\text { [kunji]. }\end{array}$ \\
\hline
\end{tabular}

\subsection{Perubahan Bunyi Fonem Konsonan /r/ Dengan Fonem Konsonan /R/}

Berikut ini adalah data yang termasuk ke dalam perubahan bunyi fonem konsonan /r/ dengan fonem konsonan /R/ pada suku kata pertama, kedua, dan ketiga tanpa mengubah arti yang terjadi akibat interferensi dialek Melayu Natuna pada acara musyawarah di Desa Pengadah, Desa Tanjung, Desa Limau Manis, Desa Selemam, dan Desa Kelanga. Pelatihan di Desa Ceruk. Pelantihan di Desa Sebadai Hulu, Kecamatan Bunguran Timur Laut sebagai berikut: a. Perubahan Bunyi Fonem Konsonan /r/ Dengan Fonem Konsonan /R/ Pada Suku Kata Pertama

\begin{tabular}{|l|l|l|l|}
\hline $\begin{array}{l}\text { Fonem } \\
\text { konson } \\
\text { an }\end{array}$ & $\begin{array}{l}\text { Baha } \\
\text { Sa } \\
\text { Indo } \\
\text { nesia }\end{array}$ & $\begin{array}{l}\text { Bahasa } \\
\text { Melayu } \\
\text { dialek } \\
\text { Melayu } \\
\text { Natuna }\end{array}$ & Pembahasan \\
\hline$/ r / \rightarrow / R /$ & rapat & [Rapat] & $\begin{array}{l}\text { Pada kata rapat } \\
\text { mengalami bunyi } \\
\text { perubahan bunyi } \\
\text { fonem konsonan } \\
\text { /r/dengan fonem } \\
\text { konsonan /R/ } \\
\text { pada suku kata } \\
\text { pertama, kata } \\
\text { sehingga kat berubah } \\
\text { [rapat] bat } \\
\text { menjadi [Rapat]. }\end{array}$ \\
\hline
\end{tabular}

b. Perubahan Bunyi Fonem Konsonan /r/ Dengan Fonem Konsonan /R/ Pada Suku Kata Kedua

\begin{tabular}{|c|c|c|c|}
\hline $\begin{array}{l}\text { Fonem } \\
\text { konson } \\
\text { an }\end{array}$ & $\begin{array}{l}\text { Baha } \\
\text { sa } \\
\text { Indo } \\
\text { nesia }\end{array}$ & $\begin{array}{l}\text { Bahasa } \\
\text { Melayu } \\
\text { dialek } \\
\text { Melayu } \\
\text { Natuna }\end{array}$ & Pembahasan \\
\hline$/ \mathrm{r} / \rightarrow / \mathrm{R} /$ & dari & [daRi] & $\begin{array}{l}\text { Pada kata dari } \\
\text { mengalami } \\
\text { perubahan bunyi } \\
\text { fonem konsonan } \\
\text { /r/ dengan fonem } \\
\text { konsonan } / \mathrm{R} / \\
\text { pada suku kata } \\
\text { kedua, sehingga } \\
\text { kata [dari] } \\
\text { berubah menjadi } \\
\text { [daRi]. }\end{array}$ \\
\hline
\end{tabular}

c. Perubahan Bunyi Fonem Konsonan $/ \mathbf{r} /$ Dengan Fonem Konsonan /R/ Pada Suku Kata Ketiga

\begin{tabular}{|l|l|l|l|}
\hline $\begin{array}{l}\text { Fonem } \\
\text { konson } \\
\text { an }\end{array}$ & $\begin{array}{l}\text { Baha } \\
\text { Sa } \\
\text { Indo } \\
\text { nesia }\end{array}$ & $\begin{array}{l}\text { Bahasa } \\
\text { Melayu } \\
\text { dialek } \\
\text { Melayu } \\
\text { Natuna }\end{array}$ & Pembahasan \\
\hline$/ \mathrm{r} / \rightarrow / \mathrm{R} /$ & daera & [daeRah] & $\begin{array}{l}\text { Pada kata daerah } \\
\text { mengalami } \\
\text { perubahan bunyi } \\
\text { fonem konsonan } \\
\text { /r/ dengan fonem } \\
\text { konsonan /R/ } \\
\text { pada suku kata } \\
\text { ketiga, sehingga } \\
\text { kata [daerah] } \\
\text { berubah menjadi }\end{array}$ \\
\hline
\end{tabular}


[daeRah].

\subsection{Perubahan Bunyi Fonem Konsonan /f/ Dengan Fonem Konsonan /p/}

Berikut ini adalah data yang termasuk ke dalam perubahan bunyi fonem konsonan /f/ dengan fonem konsonan /p/ pada suku kata pertama, kedua, ketiga, keempat dan kelima tanpa mengubah arti yang terjadi akibat interferensi dialek Melayu Natuna pada acara musyawarah di Desa Pengadah, Desa Tanjung, Desa Limau Manis, Desa Selemam, dan Desa Kelanga. Pelatihan di Desa Ceruk. Pelantihan di Desa Sebadai Hulu, Kecamatan Bunguran Timur Laut sebagai berikut:

a. Perubahan Bunyi Fonem Konsonan /f/ Dengan Fonem Konsonan /p/ Pada Suku Kata Pertama

\begin{tabular}{|l|l|l|l|}
\hline $\begin{array}{l}\text { Fonem } \\
\text { konson } \\
\text { an }\end{array}$ & $\begin{array}{l}\text { Baha } \\
\text { sa } \\
\text { Indo } \\
\text { nesia }\end{array}$ & $\begin{array}{l}\text { Bahasa } \\
\text { Melayu } \\
\text { dialek } \\
\text { Melayu } \\
\text { Natuna }\end{array}$ & Pembahasan \\
\hline$/ \mathrm{f} />/ \mathrm{p} /$ & fasilit & $\begin{array}{l}\text { [pasilitas } \\
]\end{array}$ & $\begin{array}{l}\text { Pada kata } \\
\text { fasilitas } \\
\text { asengalami } \\
\text { perubahan bunyi } \\
\text { fonem konsonan } \\
\text { /f/dengan fonem } \\
\text { konsonan /p/ } \\
\text { pada suku kata } \\
\text { pertama, } \\
\text { sehingga kata } \\
\text { [fasilitas] } \\
\text { berubah menjadi } \\
\text { [pasilitas]. }\end{array}$ \\
\hline
\end{tabular}

b. Perubahan Bunyi Fonem Konsonan /f/ Dengan Fonem Konsonan /p/ Pada Suku Kata Kedua

\begin{tabular}{|l|l|l|l|}
\hline $\begin{array}{l}\text { Fonem } \\
\text { konson } \\
\text { an }\end{array}$ & $\begin{array}{l}\text { Baha } \\
\text { sa } \\
\text { Indo } \\
\text { nesia }\end{array}$ & $\begin{array}{l}\text { Bahasa } \\
\text { Melayu } \\
\text { dialek } \\
\text { Melayu } \\
\text { Natuna }\end{array}$ & Pembahasan \\
\hline$/ \mathrm{f} />/ \mathrm{p} /$ & profe & $\begin{array}{l}\text { [propesio } \\
\text { nal] }\end{array}$ & $\begin{array}{l}\text { Pada kata } \\
\text { profesional } \\
\text { mengalami } \\
\text { siona } \\
\text { fonem konsonan bunyi } \\
\text { /f/ dengan fonem } \\
\text { konsonan /p/ }\end{array}$ \\
\hline
\end{tabular}

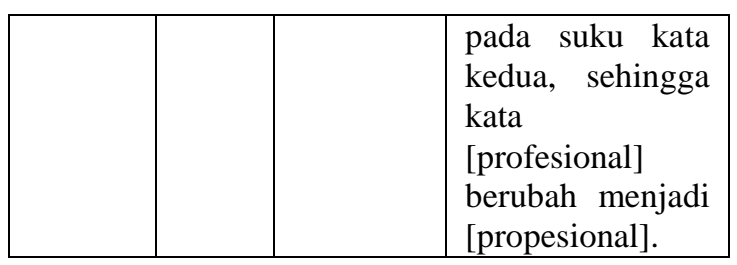

c.Perubahan Bunyi Fonem Konsonan /f/ Dengan Fonem Konsonan /p/ Pada Suku Kata Ketiga

\begin{tabular}{|l|l|l|l|}
\hline $\begin{array}{l}\text { Fonem } \\
\text { konson } \\
\text { an }\end{array}$ & $\begin{array}{l}\text { Baha } \\
\text { sa } \\
\text { Indo } \\
\text { nesia }\end{array}$ & $\begin{array}{l}\text { Bahasa } \\
\text { Melayu } \\
\text { dialek } \\
\text { Melayu } \\
\text { Natuna }\end{array}$ & Pembahasan \\
\hline$/ \mathrm{f} />/ \mathrm{p} /$ & positi & [positip] & $\begin{array}{l}\text { Pada kata positif } \\
\text { mengalami } \\
\text { perubahan bunyi } \\
\text { fonem konsonan } \\
\text { /f/ dengan fonem } \\
\text { konsonan /p/ } \\
\text { pada suku kata } \\
\text { ketiga, sehingga } \\
\text { kata [positif] } \\
\text { berubah menjadi } \\
\text { [positif].. }\end{array}$ \\
\hline
\end{tabular}

d. Perubahan Bunyi Fonem Konsonan /f/ Dengan Fonem Konsonan /p/ Pada Suku Kata Keempat

\begin{tabular}{|c|c|c|c|}
\hline $\begin{array}{l}\text { Fonem } \\
\text { konson } \\
\text { an }\end{array}$ & $\begin{array}{l}\text { Baha } \\
\text { sa } \\
\text { Indo } \\
\text { nesia }\end{array}$ & $\begin{array}{l}\text { Bahasa } \\
\text { Melayu } \\
\text { dialek } \\
\text { Melayu } \\
\text { Natuna }\end{array}$ & Pembahasan \\
\hline$/ \mathrm{f} />/ \mathrm{p} /$ & $\begin{array}{l}\text { otom } \\
\text { otif }\end{array}$ & $\begin{array}{l}\text { [otomoti } \\
\text { p] }\end{array}$ & $\begin{array}{l}\text { Pada kata } \\
\text { otomotif } \\
\text { mengalami } \\
\text { perubahan bunyi } \\
\text { fonem } \\
\text { konsonan } / \mathrm{f} / \\
\text { dengan fonem } \\
\text { konsonan } / \mathrm{p} / \\
\text { pada suku kata } \\
\text { keempat, } \\
\text { sehingga kata } \\
\text { [otomotif] } \\
\text { berubah menjadi } \\
\text { [otomotip]. }\end{array}$ \\
\hline
\end{tabular}

e. Perubahan Bunyi Fonem Konsonan /f/ Dengan Fonem Konsonan /p/ Pada Suku Kata Kelima

\begin{tabular}{|l|l|l|ll|}
\hline $\begin{array}{l}\text { Fonem } \\
\text { konson } \\
\text { an }\end{array}$ & $\begin{array}{l}\text { Baha } \\
\text { sa } \\
\text { Indo } \\
\text { nesia }\end{array}$ & $\begin{array}{l}\text { Bahasa } \\
\text { Melayu } \\
\text { dialek } \\
\text { Melayu } \\
\text { Natuna }\end{array}$ & Pembahasan \\
\\
\hline$/ \mathrm{f} />/ \mathrm{p} /$ & partis & {$[$ partisipa } & Pada & kata \\
\hline
\end{tabular}




\begin{tabular}{|l|l|l|l|}
\hline ipatif & tip] & partisipatif \\
& & mengalami \\
& & perubahan bunyi \\
& fonem konsonan \\
& & /f/ dengan fonem \\
& konsonan /p/ \\
& & pada suku kata \\
& & kelima, sehingga \\
& & kata [partisipatif] \\
& & berubah menjadi \\
& & [partisipatip]. \\
\hline
\end{tabular}

f. Perubahan Bunyi Fonem Konsonan /f/ Dengan Fonem Konsonan /p/ Pada Suku Kata Kedua dan Tiga

\begin{tabular}{|c|c|c|c|}
\hline $\begin{array}{l}\text { Fonem } \\
\text { konson } \\
\text { an }\end{array}$ & $\begin{array}{l}\text { Baha } \\
\text { sa } \\
\text { Indo } \\
\text { nesia }\end{array}$ & $\begin{array}{l}\text { Bahasa } \\
\text { Melayu } \\
\text { dialek } \\
\text { Melayu } \\
\text { Natuna }\end{array}$ & Pembahasan \\
\hline$/ \mathrm{f} />/ \mathrm{p} /$ & $\begin{array}{l}\text { efekti } \\
\text { f }\end{array}$ & [epektip] & $\begin{array}{l}\text { Pada kata efektif } \\
\text { mengalami } \\
\text { perubahan bunyi } \\
\text { fonem } \\
\text { konsonan } \\
\text { dengan fonem } \\
\text { konsonan } / \mathrm{p} / \\
\text { pada suku kata } \\
\text { kedua dan tiga, } \\
\text { sehingga kata } \\
\text { [efe?tif] berubah } \\
\text { menjadi } \\
\text { [epe?tip]. }\end{array}$ \\
\hline
\end{tabular}

g. Perubahan Bunyi Fonem Konsonan /f/ Dengan Fonem Konsonan /p/ Pada Suku Kata Kedua dan Empat

\begin{tabular}{|c|c|c|c|}
\hline $\begin{array}{l}\text { Fonem } \\
\text { konson } \\
\text { an }\end{array}$ & $\begin{array}{l}\text { Baha } \\
\text { sa } \\
\text { Indo } \\
\text { nesia }\end{array}$ & $\begin{array}{l}\text { Bahasa } \\
\text { Melayu } \\
\text { dialek } \\
\text { Melayu } \\
\text { Natuna }\end{array}$ & Pembahasan \\
\hline$/ \mathrm{f} / \rightarrow / \mathrm{p} /$ & $\begin{array}{l}\text { defen } \\
\text { itif }\end{array}$ & $\begin{array}{l}\text { [depeniti } \\
\text { p] }\end{array}$ & $\begin{array}{l}\text { Pada kata } \\
\text { defenitif } \\
\text { mengalami } \\
\text { perubahan bunyi } \\
\text { fonem konsonan } \\
\text { /f/ dengan fonem } \\
\text { konsonan /p/ } \\
\text { pada suku kata } \\
\text { kedua dan } \\
\text { keempat, } \\
\text { sehingga kata } \\
\text { [defenitif] } \\
\text { berubah menjadi } \\
\text { [depenitip]. }\end{array}$ \\
\hline
\end{tabular}

\subsection{Perubahan Bunyi Fonem Konsonan /v/ Dengan Fonem Konsonan /p/}

Berikut ini adalah data yang termasuk ke dalam perubahan bunyi fonem konsonan /v/ dengan fonem konsonan /p/ pada suku kata pertama, kedua, dan ketiga tanpa mengubah arti yang terjadi akibat interferensi dialek Melayu Natuna pada acara musyawarah di Desa Pengadah, Desa Tanjung, Desa Limau Manis, Desa Selemam, dan Desa Kelanga. Pelatihan di Desa Ceruk. Pelantihan di Desa Sebadai Hulu, Kecamatan Bunguran Timur Laut sebagai berikut:

a. Perubahan Bunyi Fonem Konsonan /v/ Dengan Fonem Konsonan /p/ Pada Suku Kata Pertama

\begin{tabular}{|c|c|c|c|}
\hline $\begin{array}{l}\text { Fonem } \\
\text { konson } \\
\text { an }\end{array}$ & $\begin{array}{l}\text { Baha } \\
\text { sa } \\
\text { Indo } \\
\text { nesia }\end{array}$ & $\begin{array}{l}\text { Bahasa } \\
\text { Melayu } \\
\text { dialek } \\
\text { Melayu } \\
\text { Natuna }\end{array}$ & Pembahasan \\
\hline$/ \mathrm{v} />/ \mathrm{p} /$ & $\begin{array}{l}\text { valid } \\
\text { asi }\end{array}$ & [palidasi] & $\begin{array}{l}\text { Pada kata } \\
\text { validasi } \\
\text { mengalami } \\
\text { perubahan bunyi } \\
\text { fonem konsonan } \\
\text { /v/ dengan fonem } \\
\text { konsonan /p/ } \\
\text { pada suku kata } \\
\text { pertama, } \\
\text { sehingga kata } \\
\text { [validasi] } \\
\text { berubah menjadi } \\
\text { [palidasi]. }\end{array}$ \\
\hline
\end{tabular}

b. Perubahan Bunyi Fonem Konsonan /v/ Dengan Fonem Konsonan /p/ Pada Suku Kata Kedua

\begin{tabular}{|l|l|l|l|}
\hline $\begin{array}{l}\text { Fonem } \\
\text { konson } \\
\text { an }\end{array}$ & $\begin{array}{l}\text { Baha } \\
\text { sa } \\
\text { Indo } \\
\text { nesia }\end{array}$ & $\begin{array}{l}\text { Bahasa } \\
\text { Melayu } \\
\text { dialek } \\
\text { Melayu } \\
\text { Natuna }\end{array}$ & Pembahasan \\
\hline$/ \mathrm{v}>/ \mathrm{p} /$ & revisi & [repisi] & $\begin{array}{l}\text { Pada kata revisi } \\
\text { mengalami bunyi } \\
\text { perubahan bunyi } \\
\text { fonem konsonan } \\
\text { /v/dengan fonem } \\
\text { konsonan /p/ } \\
\text { pada suku kata } \\
\text { kedua, sehingga } \\
\text { kata [revisi] } \\
\text { berubah menjadi } \\
\text { [repisi].]. }\end{array}$ \\
\hline
\end{tabular}


c. Perubahan Bunyi Fonem Konsonan /v/ Dengan Fonem Konsonan /p/ Pada Suku Kata Ketiga

\begin{tabular}{|c|c|c|c|}
\hline $\begin{array}{l}\text { Fonem } \\
\text { konson } \\
\text { an }\end{array}$ & $\begin{array}{l}\text { Baha } \\
\text { sa } \\
\text { Indo } \\
\text { nesia }\end{array}$ & $\begin{array}{l}\text { Bahasa } \\
\text { Melayu } \\
\text { dialek } \\
\text { Melayu } \\
\text { Natuna }\end{array}$ & Pembahasan \\
\hline$/ \mathrm{v} />/ \mathrm{p} /$ & $\begin{array}{l}\text { moti } \\
\text { vasi }\end{array}$ & $\begin{array}{l}\text { [motipasi } \\
\text { ] }\end{array}$ & $\begin{array}{l}\text { Pada kata } \\
\text { motivasi } \\
\text { mengalami } \\
\text { perubahan bunyi } \\
\text { fonem konsonan } \\
\text { /v/ dengan fonem } \\
\text { konsonan /p/ } \\
\text { pada suku kata } \\
\text { ketiga, sehingga } \\
\text { kata [motivasi] } \\
\text { berubah menjadi } \\
\text { [motipasi]. }\end{array}$ \\
\hline
\end{tabular}

\section{Perubahan Bunyi Fonem Vokal Dengan Fonem Diftong}

Berikut ini adalah data yang termasuk ke dalam perubahan bunyi fonem vokal /a/ dengan fonem diftong / $\mathrm{jw} /$ pada suku kata kedua dan ketiga tanpa mengubah arti yang terjadi akibat interferensi dialek Melayu Natuna pada acara musyawarah di Desa Pengadah, Desa Tanjung, Desa Limau Manis, Desa Selemam, dan Desa Kelanga. Pelantikan di Desa Sebadai Hulu. Pelatihan di Desa Ceruk, Kecamatan Bunguran Timur Laut sebagai berikut:

a. Perubahan Bunyi Fonem Vokal /a/ Dengan Fonem Diftong /ow/ Pada Suku Kata Kedua

\begin{tabular}{|c|c|c|c|}
\hline $\begin{array}{l}\text { Fonem } \\
\text { vokal } \\
\qquad \\
\text { fonem } \\
\text { diftong }\end{array}$ & $\begin{array}{l}\text { Baha } \\
\text { sa } \\
\text { Indo } \\
\text { nesia }\end{array}$ & $\begin{array}{l}\text { Bahasa } \\
\text { Melayu } \\
\text { dialek } \\
\text { Melayu } \\
\text { Natuna }\end{array}$ & Pembahasan \\
\hline $\begin{array}{l}\mid \mathrm{a} /> \\
/ \mathrm{Jw} /\end{array}$ & suka & [sukכw] & $\begin{array}{l}\text { Pada kata suka } \\
\text { mengalami } \\
\text { perubahan bunyi } \\
\text { fonem vokal /a/ } \\
\text { dengan fonem } \\
\text { diftong /ow/ pada } \\
\text { suku kata kedua, } \\
\text { sehingga kata } \\
\text { [suka] berubah } \\
\text { menjadi [sukJw]. }\end{array}$ \\
\hline
\end{tabular}

b. Perubahan Bunyi Fonem Vokal /a/ Dengan Fonem Diftong / ow/ Pada Suku Kata Ketiga

\begin{tabular}{|c|c|c|c|}
\hline $\begin{array}{c}\text { Fonem } \\
\text { vokal } \\
\quad V \\
\text { fonem } \\
\text { diftong }\end{array}$ & $\begin{array}{l}\text { Baha } \\
\text { sa } \\
\text { Indo } \\
\text { nesia }\end{array}$ & $\begin{array}{l}\text { Bahasa } \\
\text { Melayu } \\
\text { dialek } \\
\text { Melayu } \\
\text { Natuna }\end{array}$ & Pembahasan \\
\hline $\begin{array}{l}\mid \mathrm{a} /> \\
\text { /כw/ }\end{array}$ & ketua & [kətuəw] & $\begin{array}{l}\text { Pada kata ketua } \\
\text { mengalami } \\
\text { perubahan bunyi } \\
\text { fonem vokal /a/ } \\
\text { dengan fonem } \\
\text { diftong / ow/ pada } \\
\text { suku kata ketiga, } \\
\text { sehingga kata } \\
\text { [ketua] berubah } \\
\text { menjadi } \\
\text { [kətujw]. }\end{array}$ \\
\hline
\end{tabular}

\section{Perubahan Bunyi Fonem Vokal Dan Perubahan Bunyi Fonem Konsonan}

a. Perubahan Bunyi Fonem Vokal /o/ Dengan Fonem Vokal /u/ Pada Suku Kata Pertama Dan Perubahan Bunyi Fonem Konsonan /r/ Dengan Fonem Konsonan /R/ Pada Suku Kata Kedua

\begin{tabular}{|c|c|c|c|}
\hline $\begin{array}{l}\text { Fonem } \\
\text { vokal } \\
\text { dan } \\
\text { fonem } \\
\text { konson } \\
\text { an }\end{array}$ & $\begin{array}{l}\text { Baha } \\
\text { sa } \\
\text { Indo } \\
\text { nesia }\end{array}$ & $\begin{array}{l}\text { Bahasa } \\
\text { Melayu } \\
\text { dialek } \\
\text { Melayu } \\
\text { Natuna }\end{array}$ & Pembahasan \\
\hline $\begin{array}{l}\text { Fonem } \\
\text { vokal } \\
\text { /o/ } \rightarrow \\
\text { /u/ } \\
\text { Fonem } \\
\text { konson } \\
\text { an } \\
/ \mathrm{r} / \rightarrow \\
\text { /R/ }\end{array}$ & orang & [uRay] & $\begin{array}{lr}\text { Kata } & \text { orang } \\
\text { mengalami } & \\
\text { perubahan bunyi } \\
\text { fonem vokal /o/ } \\
\text { dengan fonem } \\
\text { vokal /u/ pada } \\
\text { suku pertama } \\
\text { dan pergantian } \\
\text { fonem fonem } \\
\text { konsonan } \\
\text { konsonan } \\
\text { dengan fonem } \\
\text { konsonan } \\
\text { pada suku kata } \\
\text { kedua, sehingga } \\
\text { kata } \\
\text { berubah menjadi } \\
\text { [uRan]. }\end{array}$ \\
\hline
\end{tabular}

Data di atas merupakan data yang termasuk ke dalam perubahan bunyi fonem vokal /o/ dengan fonem vokal /u/ pada suku kata pertama dan perubahan bunyi fonem konsonan $/ \mathrm{r} /$ dengan fonem 
konsonan /R/ pada suku kata kedua tanpa mengubah arti yang terjadi akibat interferensi dialek Melayu Natuna pada acara musyawarah di Desa Pengadah, Desa Tanjung, Desa Limau Manis, Desa Selemam, dan Desa Kelanga. Pelantikan di Desa Sebadai Hulu. Pelatihan Desa Ceruk, Kecamatan Bunguran Timur Laut.

b. Perubahan Bunyi Fonem Vokal /a/ Dengan Fonem Vokal /e/ Pada Suku Kata Pertama Dan Perubahan Bunyi Fonem Konsonan /r/ Dengan Fonem Konsonan /R/ Pada Suku Kata Kedua

\begin{tabular}{|c|c|c|c|}
\hline $\begin{array}{l}\text { Fonem } \\
\text { vokal } \\
\text { dan } \\
\text { fonem } \\
\text { konson } \\
\text { an }\end{array}$ & $\begin{array}{l}\text { Baha } \\
\text { sa } \\
\text { Indo } \\
\text { nesia }\end{array}$ & $\begin{array}{l}\text { Bahasa } \\
\text { Melayu } \\
\text { dialek } \\
\text { Melayu } \\
\text { Natuna }\end{array}$ & Pembahasan \\
\hline $\begin{array}{l}\text { Fonem } \\
\text { vokal } \\
\text { /a/ } \rightarrow \\
\text { /e/ } \\
\text { Fonem } \\
\text { konson } \\
\text { an } \\
\text { /r/ } \rightarrow \\
\text { /R/ }\end{array}$ & baru & [beRu] & $\begin{array}{l}\text { Kata } \\
\text { mengalami } \\
\text { perubahan bunyi } \\
\text { fonem vokal /a/ } \\
\text { dengan fonem } \\
\text { vokal /e/ pada } \\
\text { suku rata } \\
\text { pertama ran } \\
\text { perubahan bunyi } \\
\text { fonem konsonan } \\
\text { /r/ dengan fonem } \\
\text { konsonan } / \mathrm{R} / \\
\text { pada suku kata } \\
\text { kedua, sehingga } \\
\text { kata } \\
\text { berubah menjadi } \\
\text { [beRu]. }\end{array}$ \\
\hline
\end{tabular}

Data di atas merupakan data yang termasuk ke dalam perubahan bunyi fonem vokal /a/ dengan fonem vokal /e/ pada suku kata pertama dan perubahan bunyi fonem konsonan $/ \mathrm{r} /$ dengan fonem konsonan /R/ pada suku kata kedua tanpa mengubah arti yang terjadi akibat interferensi dialek Melayu Natuna pada acara musyawarah di Desa Pengadah, Desa Tanjung, Desa Limau Manis, Desa Selemam, dan Desa Kelanga. Pelatihan di Desa Ceruk, Kecamatan Bunguran Timur Laut.

\section{Perubahan Bunyi Fonem Konsonan Dan Perubahan Bunyi Fonem Vokal}

Berikut ini adalah data yang termasuk ke dalam perubahan bunyi fonem konsonan /r/ dengan fonem konsonan /R/ dan perubahan bunyi fonem vokal /u/ dengan fonem vokal /o/ pada suku kedua dan ketiga tanpa mengubah arti yang terjadi akibat interferensi dialek Melayu Natuna pada acara musyawarah di Desa Tanjung, Desa Limau Manis, Desa Selemam, Desa Kelanga. Pelatihan di Desa Ceruk, Kecamatan Bunguran Timur Laut sebagai berikut:

a. Perubahan Bunyi Fonem Konsonan /r/ Dengan Fonem Konsonan /R/ Dan Perubahan Bunyi Fonem Vokal /u/ Dengan Fonem Vokal /o/ Pada Suku Kata Kedua

\begin{tabular}{|c|c|c|c|}
\hline $\begin{array}{l}\text { Fonem } \\
\text { konson } \\
\text { an } \\
\text { dan } \\
\text { fonem } \\
\text { vokal }\end{array}$ & $\begin{array}{l}\text { Baha } \\
\text { sa } \\
\text { Indo } \\
\text { nesia }\end{array}$ & $\begin{array}{l}\text { Bahasa } \\
\text { Melayu } \\
\text { dialek } \\
\text { Melayu } \\
\text { Natuna }\end{array}$ & Pembahasan \\
\hline $\begin{array}{l}\text { Fonem } \\
\text { konson } \\
\text { an } \\
/ \mathrm{r} />\mathrm{R} / \\
\text { Fonem } \\
\text { vokal } \\
/ \mathrm{u} / \rightarrow \\
\mathrm{lo} /\end{array}$ & suruh & [suRoh] & $\begin{array}{l}\text { Pada kata suruh } \\
\text { mengalami } \\
\text { perubahan bunyi } \\
\text { fonem konsonan } \\
\text { /r/ dengan fonem } \\
\text { konsonan /R/ dan } \\
\text { perubahan bunyi } \\
\text { fonem vokal /u/ } \\
\text { dengan fonem } \\
\text { vokal /o/ pada } \\
\text { suku kata kedua, } \\
\text { sehingga kata } \\
\text { [suruh] berubah } \\
\text { menjadi [suRoh]. }\end{array}$ \\
\hline
\end{tabular}

b. Perubahan Bunyi Fonem Konsonan /r/ Dengan Fonem Konsonan /R/ Dan Perubahan Bunyi Fonem Vokal/u/ Dengan Fonem Vokal /o/ Pada Suku Kata Ketiga

\begin{tabular}{|c|c|c|c|}
\hline $\begin{array}{l}\text { Fonem } \\
\text { konson } \\
\text { an } \\
\text { dan } \\
\text { fonem } \\
\text { vokal }\end{array}$ & $\begin{array}{l}\text { Baha } \\
\text { sa } \\
\text { Indo } \\
\text { nesia }\end{array}$ & $\begin{array}{l}\text { Bahasa } \\
\text { Melayu } \\
\text { dialek } \\
\text { Melayu } \\
\text { Natuna }\end{array}$ & Pembahasan \\
\hline $\begin{array}{l}\text { Fonem } \\
\text { konson } \\
\text { an } \\
/ \mathrm{r} / \rightarrow \mathrm{R} / \\
\text { Fonem } \\
\text { vokal } \\
/ \mathrm{u} / \rightarrow \\
\mathrm{lo} /\end{array}$ & $\begin{array}{l}\text { menu } \\
\text { rut }\end{array}$ & $\begin{array}{l}{[\text { menuRo }} \\
\text { t] }\end{array}$ & $\begin{array}{l}\text { Pada kata } \\
\text { menurut } \\
\text { mengalami } \\
\text { perubahan bunyi } \\
\text { fonem konsonan } \\
/ \mathrm{r} / \text { dengan fonem } \\
\text { konsonan /R/ dan } \\
\text { perubahan bunyi }\end{array}$ \\
\hline
\end{tabular}




\begin{tabular}{|l|l|l|}
\hline & $\begin{array}{l}\text { fonem vokal /u/ } \\
\text { dengan fonem } \\
\text { vokal /o/ pada } \\
\text { suku kata ketiga, } \\
\text { sehingga kata } \\
\text { [menurut }] \\
\text { berubah menjadi } \\
\text { [mənuRot] }\end{array}$ \\
\hline
\end{tabular}

c. Perubahan Bunyi Fonem Konsonan /p/ Dengan Fonem Konsonan /b/ Dan Perubahan Bunyi Fonem Vokal/u/ Dengan Fonem Vokal /o/ Pada Suku Kata Kedua

\begin{tabular}{|c|c|c|c|}
\hline $\begin{array}{l}\text { Fonem } \\
\text { konson } \\
\text { an } \\
\text { dan } \\
\text { fonem } \\
\text { vokal } \\
\end{array}$ & $\begin{array}{l}\text { Baha } \\
\text { sa } \\
\text { Indo } \\
\text { nesia }\end{array}$ & $\begin{array}{l}\text { Bahasa } \\
\text { Melayu } \\
\text { dialek } \\
\text { Melayu } \\
\text { Natuna }\end{array}$ & Pembahasan \\
\hline $\begin{array}{l}\text { Fonem } \\
\text { konson } \\
\text { an } \\
/ \mathrm{p} / \rightarrow / \mathrm{b} / \\
\text { Fonem } \\
\text { vokal } \\
/ \mathrm{u} / \rightarrow \\
/ \mathrm{o} /\end{array}$ & $\begin{array}{l}\text { kamp } \\
\text { ung }\end{array}$ & $\begin{array}{l}\text { [kambon } \\
]\end{array}$ & $\begin{array}{l}\text { Pada kampung } \\
\text { mengalami } \\
\text { perubahan bunyi } \\
\text { fonem konsonan } \\
\text { /p/ dengan fonem } \\
\text { konsonan /b/ dan } \\
\text { perubahan bunyi } \\
\text { fonem vokal /u/ } \\
\text { dengan fonem } \\
\text { vokal /o/ pada } \\
\text { suku kata kedua, } \\
\text { sehingga kata } \\
\text { [kampung] } \\
\text { berubah menjadi } \\
\text { [kamboy]. }\end{array}$ \\
\hline
\end{tabular}

d. Perubahan Bunyi Fonem Konsonan /r/ Dengan Fonem Konsonan /R/ Dan Perubahan Bunyi Vokal /a/ Dengan Fonem Vokal /ə/ Pada Suku Kata Kedua

\begin{tabular}{|c|c|c|c|}
\hline $\begin{array}{l}\text { Fonem } \\
\text { konson } \\
\text { an } \\
\text { dan } \\
\text { fonem } \\
\text { vokal }\end{array}$ & $\begin{array}{l}\text { Baha } \\
\text { sa } \\
\text { Indo } \\
\text { nesia }\end{array}$ & $\begin{array}{l}\text { Bahasa } \\
\text { Melayu } \\
\text { dialek } \\
\text { Melayu } \\
\text { Natuna }\end{array}$ & Pembahasan \\
\hline $\begin{array}{l}\text { Fonem } \\
\text { konson } \\
\text { an } \\
/ \mathrm{r} />\text { /R/ } \\
\text { Fonem } \\
\text { vokal } \\
/ \mathrm{a} / \rightarrow \\
/ \mathrm{\partial} /\end{array}$ & cara & [caRə] & $\begin{array}{l}\text { Kata cara } \\
\text { mengalami } \\
\text { perubahan bunyi } \\
\text { fonem konsonan } \\
\text { /r/ dengan fonem } \\
\text { konsonan /R/ dan } \\
\text { perubahan bunyi } \\
\text { fonem vokal /a/ } \\
\text { dengan fonem } \\
\text { vokal /o/ pada } \\
\text { suku kata kedua, } \\
\text { sehingga kata }\end{array}$ \\
\hline
\end{tabular}

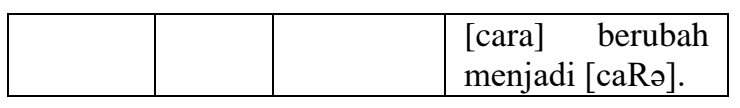

\section{Perubahan Bunyi Fonem Konsonan Dan Fonem Vokal Dengan Fonem Diftong}

Berikut ini adalah data yang termasuk ke dalam perubahan bunyi fonem konsonan /r/ dengan fonem konsonan /R/ dan perubahan bunyi fonem vokal /a/ dengan fonem diftong / $\mathrm{ww} /$ pada suku kedua dan ketiga tanpa mengubah arti yang terjadi akibat interferensi dialek Melayu Natuna pada acara musyawarah di Desa Pengadah, Desa Tanjung, Desa Limau Manis, Desa Selemam, dan Desa Kelanga. Pelatihan di Desa Ceruk, Kecamatan Bunguran Timur Laut sebagai berikut:

a. Perubahan Bunyi Fonem Konsonan /r/ Dengan Fonem Konsonan /R/ Dan Perubahan Bunyi Fonem Vokal /a/ Dengan Fonem Diftong / ow/ Pada Suku Kata Kedua

\begin{tabular}{|c|c|c|c|}
\hline $\begin{array}{l}\text { Fonem } \\
\text { konson } \\
\text { an } \\
\text { dan } \\
\text { fonem } \\
\text { vokal }\end{array}$ & $\begin{array}{l}\text { Baha } \\
\text { sa } \\
\text { Indo } \\
\text { nesia }\end{array}$ & $\begin{array}{l}\text { Bahasa } \\
\text { Melayu } \\
\text { dialek } \\
\text { Melayu } \\
\text { Natuna }\end{array}$ & Pembahasan \\
\hline $\begin{array}{l}\text { Fonem } \\
\text { konson } \\
\text { an } \\
/ \mathrm{r} />\text { /R/ } \\
\text { Fonem } \\
\text { vokal } \\
\text { /a/ } \rightarrow \\
\text { /Jw/ }\end{array}$ & $\begin{array}{l}\text { kira- } \\
\text { kira }\end{array}$ & $\begin{array}{l}\text { [kiRכw- } \\
\text { kiRวw] }\end{array}$ & $\begin{array}{l}\text { Pada kata kira- } \\
\text { kira mengalami } \\
\text { perubahan bunyi } \\
\text { fonem konsonan } \\
\text { /r/ dengan fonem } \\
\text { konsonan /R/ dan } \\
\text { perubahan bunyi } \\
\text { fonem vokal /a/ } \\
\text { dengan fonem } \\
\text { diftong / ow/ pada } \\
\text { suku kata kedua, } \\
\text { sehingga kata } \\
\text { [kira-kira] } \\
\text { berubah menjadi } \\
\text { [kiRəw-kiRəw]. }\end{array}$ \\
\hline
\end{tabular}

b.Perubahan Bunyi Fonem Konsonan /r/ Dengan Fonem Konsonan /R/ Dan Perubahan Bunyi Fonem Vokal /a/ Dengan Fonem Diftong / $\supset$ w/ Pada Suku Kata Ketiga

\begin{tabular}{|l|l|l|l|}
\hline Fonem & Baha & Bahasa & Pembahasan \\
konson & sa & Melayu & \\
an & Indo & dialek & \\
dan & nesia & Melayu & \\
\hline
\end{tabular}




\begin{tabular}{|c|c|c|c|}
\hline $\begin{array}{l}\text { fonem } \\
\text { vokal }\end{array}$ & & Natuna & \\
\hline $\begin{array}{l}\text { Fonem } \\
\text { konson } \\
\text { an } \\
/ \mathrm{r} />\mathrm{R} / \mathrm{k} \\
\text { Fonem } \\
\text { vokal } \\
\text { /a/ } \rightarrow \\
\text { low/ }\end{array}$ & suara & [suaRow] & $\begin{array}{l}\text { Pada kata suara } \\
\text { mengalami } \\
\text { perubahan bunyi } \\
\text { fonem konsonan } \\
\text { /r/ dengan fonem } \\
\text { konsonan /R/ dan } \\
\text { perubahan bunyi } \\
\text { fonem vokal /a/ } \\
\text { dengan fonem } \\
\text { diftong /ow/pada } \\
\text { suku kata ketiga, } \\
\text { sehingga kata } \\
\text { [suara] berubah } \\
\text { menjadi } \\
\text { [suaRəw]. }\end{array}$ \\
\hline
\end{tabular}

\section{SIMPULAN}

Berdasarkan hasil analisis pada bab pembahasan, dapat disimpulkan bahwa telah ditemukannya interferensi fonologi jenis perubahan bunyi fonem vokal, fonem konsonan, fonem vokal menjadi fonem diftong dalam penggunaan bahasa Indonesia pada komunikasi formal di ruang publik yang dipengaruhi oleh dialek Melayu Natuna pada situasi formal yang diselenggarakan oleh 7 Desa yaitu acara musyawarah di Desa Pengadah, Desa Tanjung, Desa Limau Manis, Desa Selemam, dan Desa Kelanga. Pelantikan di Desa Sebadai Hulu. Pelatihan di Desa Ceruk. Dari tujuh Desa tersebut ditemukan beberapa perubahan bunyi fonem yaitu perubahan bunyi fonem vokal /a/ berubah menjadi fonem vokal /o/ dan perubahan bunyi fonem vokal /a/ berubah menjadi fonem diftong /Jw/. Perubahan bunyi fonem vokal /i/ berubah menjadi fonem vokal /e/. Perubahan bunyi fonem vokal /u/ berubah menjadi fonem vokal /o/. Perubahan bunyi fonem vokal /o/ berubah menjadi fonem vokal /u/. Perubahan bunyi fonem konsonan $/ \mathrm{r}$ / berubah menjadi fonem konsonan /R/. Perubahan bunyi fonem konsonan /f/ berubah menjadi fonem konsonan /p/ dan Perubahan bunyi fonem konsonan $/ \mathrm{v} /$ berubah menjadi fonem konsonan $/ \mathrm{p} /$.

Namun ada beberapa, perubahan bunyi fonem vokal, fonem konsonan, fonem vokal menjadi fonem diftong yang hanya ditemukan di Desa tertentu misalnya perubahan bunyi fonem vokal /a/ berubah menjadi fonem vokal /e/, dan /i/. Perubahan bunyi fonem konsonan /p/ berubah menjadi fonem konsonan /b/. Perubahan bunyi fonem konsonan /l/ berubah menjadi fonem konsonan /?/. Perubahan bunyi fonem vokal /a/ berubah menjadi fonem vokal /i/. Perubahan bunyi fonem konsonan /t/ berubah menjadi fonem konsonan /d/. Perubahan bunyi fonem konsonan $/ \mathrm{k} /$ berubah menjadi fonem konsonan /g/. Perubahan bunyi perubahan bunyi bunyi fonem konsonan /c/ berubah menjadi fonem konsonan $/ \mathrm{j} /$.

\section{UCAPAN TERIMA KASIH}

Terimakasih peneliti ucapkan kepada Ibu Wahyu Indrayati, Ibu Riau Wati, Ibu Indah Pujiastuti, dan Bapak Abdul Malik, yang telah membimbing, mendukung, memotivasi, serta memberikan saran yang bermanfaat bagi peneliti.

\section{DAFTAR PUSTAKA}

Aslinda dan Syafyahya, Leni. 2010. Pengantar Sosiolinguistik. Bandung: PT Refika Aditama.

Malik, Abdul. 2016. Penelitian Deskriptif untuk Bidang Pendidikan, Bahasa, Sastra Dan Sosial-Budaya. Tanjungpinang: FKIP Universitas Maritim Raja Ali Haji

Sugiyono. 2014. Memahami penelitian kualitatif. Bandung: Alfabeta.

Wati, Riau. 2015. Pembinaan \& pengembangan bahasa Indonesia. Tanjungpinang: Universitas Maritim Raja Ali Haji 